\title{
Intersections Between Diversity Management and Human Resources Management in Polish Enterprises
}

DOI: http://dx.doi.org/10.12775/JCRL.2017.028

\author{
JOLANTA MAJ \\ Opole University of Technology, Opole, Poland \\ e-mail: j.maj@po.opole.pl
}

\begin{abstract}
Purpose: The organisational environment enterprises operate in is constantly changing. Organisations and whole industries seek new ways of achieving competitive advantage and becoming innovative. Additionally socio-demographic changes like population ageing, migrations force organisations to adapt their management styles. One of the possible solutions for those challenges is diversity management. The main goal of this paper is to identify the intersections between diversity management and human resources management in organisations and in consequence to determine where in the organisations' structure and strategy diversity management is being implemented in the analysed organisations.

Design/methodology/approach: For the purpose of this paper telephone-depth-interviews (TDIs) with representatives from companies implementing diversity management were conducted. The enterprises were chosen through purposive sampling. The organisations were firstly screened for implementing diversity management through an analysis of their websites and reports. The organisations implementing diversity management and informing stakeholders about it through their websites and reports were further included into the study. The respondents chosen for the TDIs were representatives of the organisations responsible for diversity management or indicated by the company itself as the most competent to give information about the diversity management related actions of organisations.
\end{abstract}


Findings: The conducted research suggests that analysed organisations implement a wide range of possible HR approaches to diversity management from diversity enlargement, implemented by most of the organisations through a special diversity oriented recruitment process, diversity sensitivity achieved mostly through diversity trainings, diversity audit realized through social and diversity indicators and reporting to the strategy for achieving organisational outcomes implemented by single organisations through developing a horizontal approach to diversity management.

Research and practical limitations/implications: For the purpose of this paper a qualitative research approach was chosen. Therefore, the presented results are not representative, but, due to the fact that only a few organisations in Poland implement diversity management, the entities interviewed for the purpose of this paper can be treated as flagships of this strategy in Poland and as a kind of good practices.

Originality/value: The paper examines the intersections between diversity management and human resources management in selected Polish organisations. Due to the fact that diversity management is not a widespread approach in Polish organisations, the paper gives insight into the exiting solutions of implementing it and combining it with human resources management.

Paper type: research paper.

Keywords: diversity management, human resources management, diversity enlargement, diversity sensitivity.

\section{Introduction}

Nowadays enterprises operate in a constantly changing organisational environment. Organisations and whole industries seek new ways of achieving competitive advantage and becoming innovative (Bębenek, 2015b; Bębenek, 2016b). They invest in research and development (Zygmunt, A., 2015), new technologies or invest in actions that enhance the competence of employees (Bębenek, 2015a; Bębenek, 2016a). Due to several socio-demographic processes influencing the functioning of organisations, including migrations, population ageing, globalisation, diversity management is being perceived as one of the possible strategies to cope with those processes. Therefore diversity management gradually becomes an important issue in organisations also in Poland. However, as it directly influences the workforce of the organisations it 
is also considered to be one of the most important challenges for human resources management (Alcázar, Fernández and Gardey, 2013). Therefore, the main goal of this paper is to identify the intersections between diversity management and human resources management in organisations and in consequence to determine where in the organisations' structure and strategy diversity management is being implemented.

While analysing the essence of concepts, methods and techniques of management, Jagoda (1999) distinguished two layers: the ideological and the utilitarian layer. The ideological layer is, among others a response to the challenges of the environment, changing under the influence of socio-demographic processes or the emergence of new management paradigms. The ideological layer is reduced to the creation of new systems of values, objectives and mechanisms of functioning of enterprises. Very often diversity management is being implemented only within this layer, becoming one of the PR tools of the organisation. Some organisations perceive diversity management, in a similar way to corporate social responsibility, as a marketing strategy (Drewniak, 2013) or they simply implement it as a result of following trends, a fashion or being politically correct (Skrzypczyńska, 2014). The utilitarian level consists of tools of different complexity, which are aimed at implementing an idea and connected with it values into the organisation. This is also the level on which diversity management and human resources management will intersect.

\section{Diversity management and human resources management}

Diversity management may be perceived as a horizontal strategy, intersecting with many other strategies and policies implemented in an organisation. For instance, there are many intersections between diversity management and corporate social responsibility (Jamali and Dirani, 2014; Maj, 2017) or corporate governance (Hernik and Minguez Vera, 2017). According to Starostka-Patyk, Tomski and Zawada (2015) CSR is closely related to human resources management. According to these authors, the common denominator is the group of internal stakeholders - the most valuable assets of the organisation - the human resources. Other researchers suggest even that diversity management is strictly a strategy within human resources management (Subeliani and Tsogas, 2005). Previous studies show, that the involvement of human resources 
management in diversity management is a significant challenge (Jabbour and Santos, 2008; Fleury, 1999). According to Jabbour, Gordono, Oliveira, Martinez and Battistelle (2011) there is a set of human resources practices, that through including diversity could support diversity management practices, including human resources planning, recruiting and selecting, integrating human resources, analysis and description of functions, performance assessment, remuneration and incentives, hygiene and work safety, professional and personal development or human resources audit and control. The importance of including diversity management into human resources practices has been analysed in relation to various processes: motivation (Wziątek-Staśko, 2014; Maj, 2016), recruitment (Dolot, 2014; Józefowicz and Jedynak, 2016), training and development (Dagher, D’Netto and Sohal, 1998; Beaver and Hutchings, 2005), talent management (Hanif, Shao, Ziaullah and Hanif, 2014; Piech, 2016), remuneration (Dagher et al., 1998), performance assessment (Dagher et al., 1998), human resources audit and control (Cukier and Smarz, 2012).

The connection between diversity management and human resources management led to the development of the human resources paradigm in diversity management (Mor Barak, 2010). Kossek, Lobel and Brown (2006) connected human resources management practices and workforce diversity with individual, group and organisational outcomes. Kossek and Lobel (1996) developed a model of HR approaches to diversity management presented in Table 1.

Table 1. Human resources approaches to diversity management

\begin{tabular}{llll}
\hline HR Approach & Goal & Assumption & Strategy \\
\hline $\begin{array}{l}\text { Diversity } \\
\text { enlargement }\end{array}$ & $\begin{array}{l}\text { To create diversity } \\
\text { by changing work- } \\
\text { force composition } \\
\text { and increase their } \\
\text { diversity }\end{array}$ & $\begin{array}{l}\text { Increasing diversity } \\
\text { and exposure to } \\
\text { diversity will } \\
\text { lead to improved } \\
\text { performance. No } \\
\text { additional changes } \\
\text { are needed }\end{array}$ & $\begin{array}{l}\text { To recruit diverse } \\
\text { employees }\end{array}$ \\
\hline $\begin{array}{l}\text { Diversity } \\
\text { sensitivity }\end{array}$ & $\begin{array}{l}\text { To promote commu- } \\
\text { nication and under- } \\
\text { standing and build } \\
\text { relationships among } \\
\text { diverse employees }\end{array}$ & $\begin{array}{lll}\text { Increased sensitivity } \\
\text { positively affects }\end{array}$ & $\begin{array}{l}\text { Diversity trainings } \\
\text { addressed to all } \\
\text { employees }\end{array}$ \\
& & & \\
\hline
\end{tabular}




\begin{tabular}{llll}
\hline HR Approach & Goal & Assumption & Strategy \\
\hline Cultural audit & $\begin{array}{l}\text { To identify obstacles } \\
\text { faced by diverse } \\
\text { employees and } \\
\text { modify organi- } \\
\text { sations practices } \\
\text { accordingly }\end{array}$ & $\begin{array}{l}\text { The dominant } \\
\text { culture, favouring } \\
\text { white males, hurts } \\
\text { the performance of } \\
\text { diverse employees } \\
\text { and needs to be } \\
\text { adjusted }\end{array}$ & $\begin{array}{l}\text { The current state is } \\
\text { being diagnosed and } \\
\text { assessed through } \\
\text { using surveys and } \\
\text { focus groups }\end{array}$ \\
\hline $\begin{array}{l}\text { Strategy for } \\
\text { achieving } \\
\text { organisational } \\
\text { outcomes }\end{array}$ & $\begin{array}{l}\text { To achieve organ- } \\
\text { isational goals } \\
\text { through diversity } \\
\text { management }\end{array}$ & $\begin{array}{l}\text { Diversity man- } \\
\text { agement has to be } \\
\text { linked to the desired } \\
\text { outcomes }\end{array}$ & $\begin{array}{l}\text { Diversity man- } \\
\text { agement has to be } \\
\text { integrated into HR } \\
\text { and other strategies }\end{array}$ \\
\hline
\end{tabular}

Table 1.

continued

Source: Based on: Kossek and Lobel (1996) and Mor Barak (2010).

This model shows the possible intersections between human resources management and diversity management. It should however be stressed out that especially the first three presented HR approaches are not exclusive and may be implemented with different proportions together. The fourth approach may be perceived as the most general one including also the previous models.

\section{Research design and methodology}

Diversity management is not a very popular approach among Polish organisations (Maj and Walkowiak, 2015) Therefore, in order to answer the main research question of how diversity management intersects with human resources management in Polish organisations, a qualitative research approach was chosen. Thus, the presented results are not representative, but, due to the fact that only a few organisations in Poland implement diversity management, the entities interviewed for the purpose of this paper can be treated as flagships of this strategy in Poland and as a kind of good practices.

For the purpose of this paper telephone-depth-interviews (TDIs) were conducted. The TDIs were conducted with representatives from the companies which signed the Polish Diversity Charter. The enterprises were chosen through purposive sampling. The signatories of the Diversity Charter were firstly screened for implementing diversity management 
through an analysis of their websites and reports. The organisations implementing diversity management and informing stakeholders about it through their websites and reports were further included into the study. Furthermore, the sample was supplemented by organisations implementing diversity management but not having signed the Diversity Charter. The respondents chosen for the TDIs were representatives of the organisations responsible for diversity management or informants indicated by companies as the most competent to give information about the organisations' diversity management related actions. The enterprises represented a wide range of industries including: services (4 organisations), banks (3 organisations), chemical industry (2 organisations) and 1 organisation from following sectors: energy, other finances, retail trade, IT, hotels, building materials, food industry, basic materials industry, telecommunication, transport and logistics and developer. The respondents were given a set of questions and if necessary, the answers were deepened by further questions. The interviews were transcribed and analysed using the MAXQDA software. For the purpose of this paper, the chosen parts of the interviews were translated into English. As some of the respondents insisted on anonymity, the organisations and interviews were encoded using a numbering from 1 to 20.

\section{Research results}

The conducted research has shown that the analysed organisations implement diversity management as a part of two strategies: corporate social responsibility (Maj, 2017) and human resources management. There are several ways of connecting diversity management and human resources management, as summarized in the model of Kossek and Lobel (1996).

Through the connection with affirmative and anti-discrimination actions, diversity management is being implemented as a part of the human resources strategy (Organisation no. 13). According to Respondent no. 15, the human resources management strategy is a kind of an umbrella for all the actions undertaken under diversity management.

As Respondent no. 14 states, the human resources department is the place where the actual work on developing and implementing diversity management takes place: "In the company [diversity management] is largely placed in HR department (...) this is where the work takes place, 
different processes are being prepared, developed...”. However as the same Respondent observes, HR is not isolated in implementing diversity management: "We have the so called business ambassadors and they are very often people occupying responsible positions, but working in the first line of managing the company (...) and they are people with whom the HR department cooperates. Many information, about what is happening in the business, comes from these people”. Also in case of Organisation no. 9, the Respondent suggests that the HR department is the actual place, where diversity management is being implemented into the organisational actions.

These [diversity management] activities are being carried out by two departments together, one person from the HR department and one from the corporate department. I am from the corporate department and I deal with the whole subject of social responsibility. I am the person who ties together these topics in the company. However at the executive and very operational level, it is the responsibility of a person from the human resources department, who at the same time is the Talent Development Specialist.

Respondent no. 10 states that:

The main business owner of this [diversity management] topic is of course the HR Department (...). [Diversity management] is based on HR instruments, that the department has and introduces: policies, regulations, various types of internal trainings, workshops, diversity network, which are being build between different actors within the group and on a specific position.

These organisations are examples of connecting diversity management with human resources management on the most basic, utilitarian level.

The interviewed organisations present a wide range of possible implementations of diversity management into human resources management and its processes. Organisation no. 15 implements diversity management into human resources by using a diversity indicator model:

One of the aspects of our management is that every six months we look at our diversity indicators, i.e. we show and discuss during the board 
meeting (...) what happens in our organisation in terms of gender, remuneration in each employee category, in terms of candidates we are recruiting. There are a lot of indicators, which show us whether diversity in our organisation really exists and whether we truly care about the equal rights of the particular groups (...). We try to balance it and we analyse in those indicators of women and men earn the same in the same positions. (...). All of this results in very interesting initiatives, which later find their place in human resources management policies.

This approach may be treated as an example of the cultural audit approach (Kossek and Lobel, 1996). This audit approach is used in recruitment, remuneration, talent development etc. Also other organisations use indicators for assessing their diversity management and equal treatment. All of the interviewed organisations state that they do report on diversity in a more or less extensive way and therefore need to collect data on the diversity of their workforce. The diversity audit approach may be as well stretched to continuous processes of monitoring changes in labour codes and related legislation and appropriate monitoring of the relevant areas of the company's operations, which has been stressed by Respondent no. 4. The diversity audit approach has also been adopted by Organisation no. 8, which has conducted an audit of the office space for the accessibility for employees with disabilities.

When looking for intersections between diversity management and human resources management the respondents point also to the recruitment process. Respondent no. 4 mentions:

(...) [within the recruitment process] we try to guarantee that the job offer does not contain information about the preferred gender/ race/age of the candidate. During the on-boarding process - the training, the candidate is undergoing during the first few days, the employee is being informed that the company implements a global diversity program.

In this case diversity management seems to be understood more like anti-discrimination than actual diversity management. For example, other organisations adapt the diversity enlargement approach by giving extra points to diverse candidates during the 
recruitment process (Organisation no. 5), try to ensure that during the recruitment process both gender are represented (Organisation no. 15) or use photos of representatives of minority groups when posting job offers (Organisation no. 14).

Starting with recruiting and being an attractive employer we changed the whole layout of our job advertisements. When we are looking for construction engineers, women dominate in all the visualizations. They show that it is possible. We show all the women who work with us. Then during the recruitment process we make sure, that candidates representing both genders, different age groups, with different experience, education background are represented.

Organisation no. 7 implements a guideline for recruitment to include on every recruitment shortlist minimum one women and to choose a woman, when as a result of the recruitment procedure two candidates (a male and a female) score the same amount of points. Organisation no. 7 also gives extra points during the recruitment process to candidates with disabilities.

Organisation no. 18 connected diversity management to training and development. As Respondent no 18 stated: “All employees or candidates, independently from the mentioned [diversity] dimensions have the same access to development initiatives, trainings or job offers. Diversity is being taken under consideration within many human resources development processes i.e. developing training offers, development programs or succession plans”. The connection between diversity management and training and development can be twofold. First of all, diversity is being treated as an indicator for the access equality to such programs, as in the case of Organisation no. 18 or Organisation no. 20. Secondly, diversity management is the subject of trainings, which then falls into the approach of diversity sensitivity (Kossek and Lobel, 1996). Such an approach has been presented e.g. by Organisation no. 16, which organises diversity open days and diversity trainings and invites people with disabilities to conduct trainings and increase the sensitivity of employees. Organisation no. 18 provides e.g. trainings for young employees as well as older employees (50+) in order to promote the exchange of knowledge and smoothen the cooperation between representatives of different generations, intercultural trainings for managers, language trainings etc. 
Some organisations, e.g. Organisation no. 3, connect diversity management with talent management but also with organisational culture.

Managing the diversity of the workforce, being open to the fact, that sometimes we employ different generations, different people with different views - this is diversity management. This is an HR approach. We really touch something called organisational culture, culture of the company, values the company has. We really touch an interesting issue: value management, which, nowadays in the cyber society is incredibly important (...). Diversity management intersects with two departments, one of which is HR, which in our company is being called 'talent \& culture'.

Some organisations implement diversity management also into the performance assessment systems, which is a result of the adoption of a competency-based system in the organisation as in the case of Organisation no. 12.

Additionally we have the company-wide competency model. These competencies are a set of behaviours, which we prefer, promote and develop. One of six competencies is openness towards change and diversity. We manage diversity through competencies. Once a year we assess these competencies in a formal way (...). We assess our attitudes, our behaviours towards diversity (...). Please believe me, that implementing openness towards change and diversity into the assessment process is very effective in terms of highlighting its importance. I do not know if there is a stronger gear.

The connections between diversity management and human resources management are also visible in terms of budgeting. Some of the analysed organisations admit, that diversity management initiatives are financed from the HR budget. Respondent no. 18 states that: "Support and promotion initiatives for diversity management are conducted within the budget for training, development and recruitment".

A few of the interviewed organisations implement the Strategy for Achieving Organisational Outcomes approach. By implementing a so-called $360^{\circ}$ system, as in Organisation no. 2, the company integrates diversity management not only into human resources 
management but also into other strategies linking it directly with the organisation's business strategy.

If someone manages people and wants to build an organisation with $360^{\circ}$ overview, if he wants to see the bigger picture, he has to have diverse teams. On the other hand, if you are an organisation active on the consumer market and you address your offer to a common consumer and does not want to limit yourself than you also need an $360^{\circ}$ overview. You need to understand different needs of diverse people, who are the organisation's customers. Here we speak of using the full potential of teams and of the market (...). [Diversity management] and the social responsibility strategy are parts of the business strategy. In the holistic organisation management this is a parts of the company's strategy. This is not a separate creation, which is somewhere on the side. This is an element of the company's strategy. We are a company, which wants a $360^{\circ}$ overview and we need to have diverse teams (...) this is why we support diversity, because only then we will have this full overview.

This approach assumes the integration of diversity management into other strategies and does not limit it to human resources. It also connects diversity management with the vision, mission and strategy of the firm and therefore is the embodiment of the mature diversity management (Wieczorek-Szymańska, 2017).

The analysed organisations present a variety of possible implementations of human resources management and diversity management. The results have been summarized in Table 2 .

Table 2. Human resources approaches to diversity management in the analysed organisations

\begin{tabular}{|c|c|c|}
\hline $\begin{array}{l}\text { HR } \\
\text { Approach }\end{array}$ & Organisations & Practices \\
\hline \multirow{5}{*}{$\begin{array}{l}\text { Diversity } \\
\text { enlarge- } \\
\text { ment }\end{array}$} & Organisation no. 5 & Extra points for minorities \\
\hline & Organisation no. 7 & \\
\hline & Organisation no. 4 & Diversity neutral job offers \\
\hline & $\begin{array}{l}\text { Organisation no. } 7 \\
\text { Organisation no. } 15\end{array}$ & $\begin{array}{l}\text { Guidelines for recruitment (min. one women on } \\
\text { the shortlist) }\end{array}$ \\
\hline & Organisation no. 14 & $\begin{array}{l}\text { Job offers use photos of representatives of } \\
\text { minority groups }\end{array}$ \\
\hline
\end{tabular}


Table 2. continued

\begin{tabular}{|c|c|c|}
\hline $\begin{array}{l}\text { HR } \\
\text { Approach }\end{array}$ & Organisations & Practices \\
\hline \multirow[t]{3}{*}{$\begin{array}{l}\text { Diversity } \\
\text { sensitivity }\end{array}$} & $\begin{array}{l}\text { Organisation no. } 13 \\
\text { Organisation no. } 20\end{array}$ & $\begin{array}{l}\text { Diversity management identified with antidis- } \\
\text { crimination policy }\end{array}$ \\
\hline & Organisation no. 3 & $\begin{array}{l}\text { Diversity management as a part of organisa- } \\
\text { tional culture and value management }\end{array}$ \\
\hline & $\begin{array}{l}\text { Organisation no. } 16 \\
\text { Organisation no. } 18\end{array}$ & Diversity trainings \\
\hline \multirow{5}{*}{$\begin{array}{l}\text { Cultural } \\
\text { audit }\end{array}$} & Organisation no. 15 & Diversity indicator model \\
\hline & $\begin{array}{l}\text { Organisation no. } 18 \\
\text { Organisation no. } 20 \\
\end{array}$ & $\begin{array}{l}\text { Diversity as an indicator for accessibility of } \\
\text { trainings }\end{array}$ \\
\hline & Organisation no. 8 & Audit of office space \\
\hline & Organisation no. 4 & $\begin{array}{l}\text { Continuous processes of monitoring changes in } \\
\text { labour codes and related legislation }\end{array}$ \\
\hline & Organisation no. 1 & $\begin{array}{l}\text { Social reporting (including single diversity } \\
\text { indicators) }\end{array}$ \\
\hline \multirow{2}{*}{$\begin{array}{l}\text { Strategy } \\
\text { for achiev- } \\
\text { ing organ- } \\
\text { isational } \\
\text { outcomes }\end{array}$} & Organisation no. 12 & $\begin{array}{l}\text { Competency based system, which includes the } \\
\text { diversity management as a competency }\end{array}$ \\
\hline & Organisation no. 2 & $\begin{array}{l}\text { The } 360 \text { degree approach linking diversity } \\
\text { management with business strategy }\end{array}$ \\
\hline
\end{tabular}

Source: Own study.

As indicated organisations may implement more than one HR approach to diversity management. However, not all analysed organisations and their practices may be qualified into the presented model. Due to the analysis it seems that the model does not include all the possible approaches omitting the basic approach of HR to diversity management which could be labelled as the 'executive approach'. In such an approach, the HR department is simply the unit responsible for implementing single actions not resulting from a well planned diversity strategy but rather being reactive initiatives. Such an approach would be represented e.g. by Organisations no. 7, 9, 10 or 16. Those respondents, when asked, were not able to mention the examples of actual diversity management actions implemented within human resources management. 


\section{Conclusions}

Due to the fact, that employees or candidates are the recipients of both strategies: diversity management and human resources management the fact, that those strategies intersect is no surprise. However, as the state of art shows there are many possibilities for those strategies to intersect and interact. The possible approaches have been summarized within Kossek and Lobels (1996) model of human resources approaches to diversity management, which may be a basis for developing a maturity model of diversity management. The presented research adds an empirical contribution to this model, showing possible intersections of diversity management and human resources management in the analysed organisations, showing how the particular HR approaches are implemented and justified in real-life organisations.

However, the conducted research and analysis have some limitations. Due to the qualitative nature of the conducted research as well as the purposive sampling, the results and analysis presented above cannot be treated as representative but more as an exploration of the topic. Furthermore, the research sample consisted mostly of large enterprises, which is in contradiction with the general structure of organisations in Poland due to the number of employees. In some regions of Poland, microenterprises account for over 90\% of all enterprises (Zygmunt, J., 2015). Therefore a further, quantitative analysis on a representative sample of organisations would be beneficial for a wider understanding of the issue, which could be difficult because of the limited prevalence of this strategy among Polish organisations.

\section{References}

Alcázar, F.M., Fernández, P.M.R., Gardey, G.S. (2013), “Workforce Diversity in Strategic Human Resource Management Models: A Critical Review of the Literature and Implications for Future Research”, Cross Cultural Management, Vol. 20, Issue 1, pp. 39-49.

Beaver, G., Hutchings, K. (2005), “Training and Developing an Age Diverse Workforce in SMEs: The Need for a Strategic Approach”, Education and Training, Vol. 47, No. 8, pp. 592-604.

Bębenek, P. (2015a), “Bezpieczeństwo w procesie produkcji i zarządzania kompetencjami z wykorzystaniem przestrzeni wirtualnej”, in: Szwedziak, K., Tukiendorf, M., Jakubowski, T. (Eds.), Aplikacyjne i Teoretyczne Problemy w Przemyśle Rolno-Spożywczym: Interdyscyplinarne Aspekty Zdrowego Stylu Życia, Politechnika Opolska, Opole, pp. 7-16. 
Bębenek, P. (2015b), “Enterprise Innovation Management - Integration of the Process, Product, Marketing and Organisation Changes”, in: Malik, K., Dymek, Ł. (Eds.), Effective Transfer of Knowledge from Science to Industry in the Opolskie Voivodeship: Requirements for an Effective Cooperation, Difin, Warszawa, pp. 165-175.

Bębenek, P. (2016a), "Development of Employee Competencies and Their Impact on Safety at Work”, Logistyka, No. 2, pp. 2-4.

Bębenek, P. (2016b), “Zarządzanie innowacjami w przedsiębiorstwie - benchmarking kryteriów oceny innowacyjności w projektach finansowanych z funduszy unijnych”, Marketing i Rynek, No. 10, pp. 16-32.

Cukier, W., Smarz, S. (2012), “Diversity Assessment Tools: A Comparison”, International Journal of Knowledge, Culture \& Change Management, Vol. 11, Issue 6, pp. 49-63.

Dagher, J., D’Netto, B., Sohal, A.S. (1998), “Managing Workforce Diversity in the Australian Manufacturing Industry”, Human Factors and Ergonomics in Manufacturing, Vol. 8, Issue 2, pp. 177-192.

Dolot, A. (2014), "Rola procesu rekrutacji pracowników w kształtowaniu wizerunku przedsiębiorstw”, Przedsiębiorczość - Edukacja, No. 10, pp. 59-70.

Drewniak, R. (2013), “Corporate Social Responsibility in the Context of the Enterprise Marketing Activities”, Journal of Positive Management, Vol. 4, No. 1, pp. 38-51.

Fleury, M.T. (1999), “The Management of Culture Diversity: Lessons from Brazilian Companies”, Industrial Management \& Data Systems, Vol. 99, No. 3, pp. 109-114.

Hanif, M.I., Shao, Y., Ziaullah, M., Hanif, M.S. (2014), "Role of Talent Management, Diversity Trainings and HR on Effective Implementation of HR Practices in Telecom Sector in Pakistan”, Advances in Intelligent Systems and Computing, Vol. 280, pp. 761-770.

Hernik, J., Minguez Vera, A. (2017), “Searching for a Perfect Composition for a Board of Directors”, Journal of Corporate Responsibility and Leadership, Vol. 4, Issue 1, pp. 19-38.

Jabbour, C.J., Gordono, F.S., Oliveira, J.H.C.D., Martinez, J.C., Battistelle, R.A.G. (2011), "Diversity Management: Challenges, Benefits, and the Role of Human Resource Management in Brazilian Organizations”, Equality, Diversity and Inclusion, Vol. 30, Issue 1, pp. 58-74.

Jabbour, C.J., Santos, F.C. (2008), “The Central Role of Human Resource Management in the Search for Sustainable Organizations”, International Journal of Human Resources Management, Vol. 19, No. 12, pp. 2133-2154.

Jagoda, H. (1999), “Koncepcje przekrojowe w zarządzaniu przedsiębiorstwem: Więcej pytań czy odpowiedzi?”, Przegląd Organizacji, No. 2, pp. 10-12.

Jamali, D., Dirani, A. (2014), "Synergies of CSR and Diversity Management: A Converging Agenda”, in: Karataş-Özkan, W.M., Nicolopoulou, K. (Eds.), Corporate Social Responsibility and Human Resource Management, Edward Elgar Publishing Limited, Cheltenham.

Józefowicz, B., Jedynak, E. (2016), “Zarządzanie różnorodnością a budowanie zaufania w przedsiębiorstwie na przykładzie firmy Intel”, Przedsiębiorczość i Zarzq̨dzanie, Vol. XVII, Issue 2, Part 3, pp. 75-88.

Kossek, E.E., Lobel, S. (1996), "Introduction: Transforming Human Resources Systems to Manage Diversity - an Introduction and Orienting Framework”, in: 
Kossek, E.E., Lobel, S. (Eds.), Managing Diversity: Human Resource Strategies for Transforming the Workplace, Blackwell, Oxford, England, pp. 1-19.

Kossek, E.E., Lobel, S.A., Brown, J. (2006), "Human Resource Strategies to Manage Workforce Diversity: Examining 'the Business Case'”, in: Konrad, A.M., Prasad, P., Pringle, J.K. (Eds.), Handbook of Workplace Diversity, SAGE Publications, London, pp. 53-74.

Maj, J. (2016), "Wpływ zarządzania różnorodnością na system motywacyjny przedsiębiorstw”, in: Zygmunt, A., Zygmunt, J. (Eds.), Dostosowanie przedsiębiorstw do zmian otoczenia zewnętrznego: Studia i Monografie, Politechnika Opolska, Opole, pp. 103-114.

Maj, J. (2017), “Together or Apart? Diversity Management and Corporate Social Responsibility in Polish Enterprises”, in: Soliman, K. (Ed.), Proceedings of the 29th International Business Information Management Association Conference - Education Excellence and Innovation Management through Vision 2020: From Regional Development Sustainability to Global Economic Growth, IBIMA, pp. 517-523.

Maj, J., Walkowiak, Ł. (2015), “Diversity Management in Polish Organizations”, in: Proceedings of the $4^{\text {th }}$ International Virtual Conference on Advanced Research in Scientific Areas (ARSA-2015), University of Zilina, Zilina, pp. 79-82.

Mor Barak, M.E. (2010), Managing Diversity: Toward a Globally Inclusive Workplace, SAGE Publications.

Piech, S. (2016), "Performance and Talent: Essentials of International Talent Development”, in: Zeuch, M. (Ed.), Handbook of Human Resources Management, SpringerVerlag, Berlin, pp. 511-542.

Skrzypczyńska, K. (2014), “Social Responsibility of Companies Operating in Poland”, Journal of Corporate Responsibility and Leadership, Vol. 1, Issue 1, pp. 71-84.

Starostka-Patyk, M., Tomski, P., Zawada, M. (2015), "Diversity Management as a Part of Corporate Social Responsibility Policy”, International Conference on Communications, Management, and Information Technology (ICCMIT 2015), No. 65, pp. 1038-1045.

Subeliani, D., Tsogas, G. (2005), “Managing Diversity in the Netherlands: A Case Study of Rabobank”, International Journal of Human Resource Management, Vol. 16, Issue 5, pp. 831-851.

Wieczorek-Szymańska, A. (2017), “Organizational Maturity in Diversity Management”, Journal of Corporate Responsibility and Leadership, Vol. 4, Issue 1, pp. 39-54.

Wziątek-Staśko, A. (2014), "Motywatory niematerialne skutecznymi narzędziami doskonalenia procesu motywowania w organizacjach zarządzających różnorodnością - w oparciu o wyniki międzynarodowych badań empirycznych”, Zeszyty Naukowe Politechniki Ślq̨skiej: Seria Organizacja i Zarzq̨dzanie, No. 73, pp. 687-700.

Zygmunt, A. (2015), "Poziom nakładów na B+R w Polsce na tle pozostałych Państw Unii Europejskiej”, Prace Naukowe Uniwersytetu Ekonomicznego we Wrocławiu: Problemy rozwoju regionalnego i lokalnego, No. 393, pp. 163-171.

Zygmunt, J. (2015), “Entrepreneurship as a Factor of Regional Development”, Barometr Regionalny: Analizy i prognozy, Vol. 13, No. 4, pp. 119-125. 
